\title{
Ultrastructure of Aulacoseira brasiliensis sp. nov. (Coscinodiscophyceae) and comparison with related species
}

\author{
Priscila Izabel Tremarin ${ }^{1}$, Thelma Alvim Veiga Ludwig ${ }^{2}$ \& Lezilda Carvalho \\ TORGAN $^{3}$
}

${ }^{1}$ Programa de Pós-graduação. Universidade Federal do Rio Grande do Sul, Departamento de Botânica, 9500, Av. Bento Gonçalves, prédio 43433, 91501-970, Porto Alegre, Rio Grande do Sul, Brasil; *Corresponding author e-mail: ptremarin@gmail.com

${ }^{2}$ Universidade Federal do Paraná, Departamento de Botânica, Caixa Postal 19031, 81531-990, Curitiba, Paraná, Brasil

${ }_{3}^{3}$ Museu de Ciências Naturais - Fundação Zoobotânica do Rio Grande do Sul, Caixa Postal 1188, 90001-970, Porto Alegre, Rio Grande do Sul, Brasil

\begin{abstract}
This paper describes and illustrates Aulacoseira brasiliensis Tremarin, Torgan et T. Ludwig sp. nov. under light and electron microscopy and compares their ultrastructure with similar species obtained from HUSTEDT'S collection samples. The new species is characterized by forming short chains linked by ovate-attenuate spines, rounded areolae occluded by vola, undeveloped ringleist and sessile rimoportulae arranged in two circumferential alternate rows. The spines shape, rimoportulae disposition, valve surface and mantle areolation pattern are very particular. The ultrastructural features of the frustules of A. brasiliensis are compared with those of A. muzzanensis, A. agassizii var. agassizzi and $A$. agassizii var. malayensis, particularly with respect to the areolation pattern, position, number and shape of rimoportulae. A. brasiliensis was found in lotic and lentic environments of tropical and subtropical regions from Brazil.
\end{abstract}

Key words: A. agassizii, A. muzzanensis, Brazil, centric diatom, freshwater, taxonomy

\section{Introduction}

The genus Aulacoseira ThwaItes is exclusively found in continental waters and presents extensive worldwide distribution (Round et al. 1990; PotAPOVA et al. 2008). It is characterized by cylindrical frustules united by shortened linking spines, usually spatulate or forked, forming filamentous chains (Houk 2003). Most species of the genus have acute and elongated separation spines, round to rectangular areolae occluded by cribra or vola, more or less pronounced ringleist, one or more rimoportulae, often sessile and located on the mantle, close to the ringleist (Round et al. 1990; Houk 2003; Houk \& Klee 2007; Potapova et al. 2008).

Before the 70's, the taxonomy of the group was focused mainly on morphometric characters and the striation pattern observed in light microscopy. Electron microscopy allowed us to obtain further information on the internal and external structure of the cell siliceous wall.
However, the ultrastructure of several species and varieties of Aulacoseira was not studied until the present (Hickel \& HÅKANSSON 1991; DenYs et al. 2003; Tuj \& HouK 2004; Houk \& KLEe 2007), difficulting the correct identification, as well as the understanding of the diacritical features between similar species (SIVER \& KLING 1997). Actually, mantle height, valve face ornamentation, shape of spines, density, size and distribution pattern of areolae, number and shape of rimoportulae, are used to distinguish species (SIVER \& KLING 1997; Edgar \& Theriot 2003; PotAPova et al. 2008).

Currently, the genus has about 60 described species (EDGAR \& THERIOT 2004), of which only 18 were registered in Brazil. Most of these records originate from ecological or floristic studies and do not include a detailed analysis of the diatom frustules. Further studies were developed by Moro (1991) clarifying the morphology of $A$. granulata var. australiensis (Grunow) MoRo; Hickel \& HÅKANSSON (1991) analyzed the ultrastructure of $A$. herzogii (Lemmermann) Simonsen on 
samples from Amazon region; RAupp et al. (2006) described and illustrated in SEM A. ambigua (Grunow) Simonsen, $A$. distans (Ehr.) Simonsen and $A$. tenella (NygaArd) Simonsen from a south Brazilian reservoir, and Tremarin et al. (2011) studied the ultrastructure of Aulacoseira gessneri (Hustedt) Simonsen from Brazilian Pantanal.

The analysis of continental samples from Brazil showed the occurrence of an Aulacoseira species misinterpreted in the literature. Specimens of this taxon had been previously found by other Brazilian researchers in lotic and lentic environments, but with mislead identification. The first record was from BRASSAC et al. (1999) giving the taxon as $A$. agassizii, then VISINONI (2002), MoRANDI (2008) and FARIA (2010) cited the taxon as $A$. muzzanensis. This was the reason why the presented study deals with the comparison of this species with these taxa.

The species presents a particular rimoportulae disposition and a unique shape of spines. Thus, the paper proposes and describes it as the new species, Aulacoseira brasiliensis.

\section{Material and Methods}

The observations of Aulacoseira brasiliensis frustules were performed on samples obtained from plankton and periphyton from lakes and rivers located in the north (Amazonas and Pará State), mid-west (Mato Grosso State), southeast (São Paulo State) and southern (Paraná State) of Brazil (Fig. 1). Table 1 shows the samplings data.

Phytoplankton samples were collected with a net (mesh size $25 \mu \mathrm{m}$ ) and the periphyton, by scraping the stems of submerged aquatic macrophyte Potamogeton polygonus (Potamogetonaceae). Plankton samples were fixed with Lugol solution (SouRNIA 1978) and the periphyton were fixed with Transeau solution (Bicudo \& Menezes 2006). Materials from Friedrich HusteDT's collection, deposited in the Alfred Wegener Institut für Polar- und Meeresforschung (BRM), have also been observed for comparative analysis of diacritical features of the species: number A42, Melosira agassizii Ostenfeld, Lake Victoria, Africa; number AS1325, lectotype of Melosira agassizii var. malayensis Hustedt, Celesbe, Malay Arch.; number E1289, Melosira granulata var. muzzanensis (MeISTER) Hustedt, Lago di Muzzano, Italy).

Samples were cleaned using $\mathrm{KMnO}_{4}$ and $\mathrm{HCl}$ according to the SIMONSEN (1974) method modified by Moreira-Filho \& Valente-Moreira (1981). Permanent diatom preparations were mounted using Naphrax $^{\circledR}$ (R.I. $\left.=1.74\right)$ and were analyzed under an Olympus BX-40 microscope. Figures were obtained

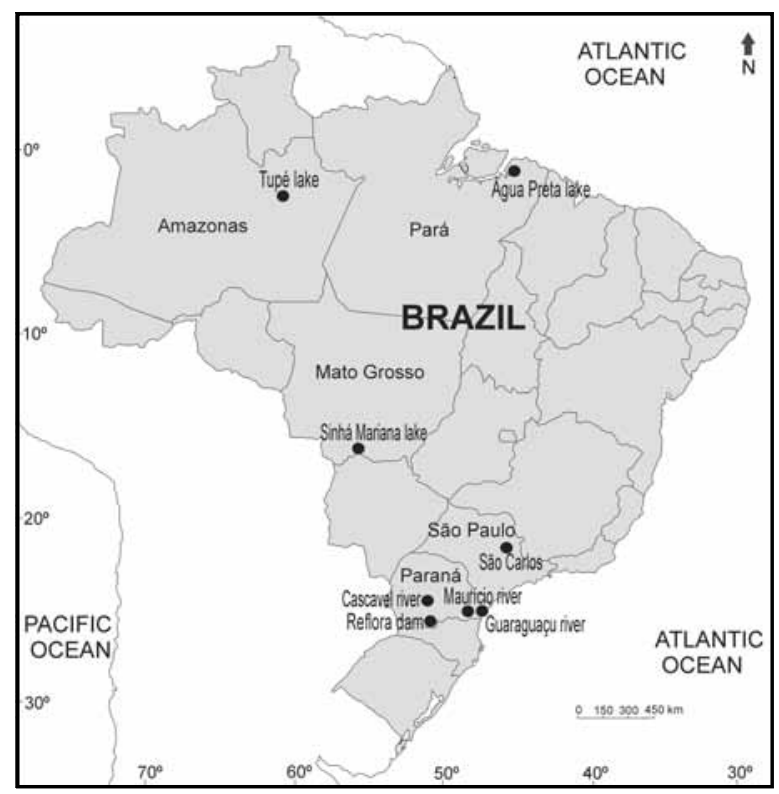

Fig.1. Localization of the sampling sites in Brazilian waters.

with Olympus DP71 image capture equipment. Part of the oxidized material was used in the preparation of aluminum supports covered with gold-palladium at $1 \mathrm{kV}$ for 5 minute in Balser Sputtering/SDC300 for analysis on a scanning electron microscope JEOL JSM 6360LV, operated at $15 \mathrm{kV}$ and $8 \mathrm{~mm}$ working distance. Breaking of some frustules was induced with acupuncture needles on the stub for the observation of internal structures. The cleaned diatom sample was transferred to a grid with 300 mesh, covered with palladium and observed with the JEOL-JEM 1200EXII transmission electron microscope (TEM), operated at $80 \mathrm{kV}$.

Valve structure description terminology follows Round et al. (1990), Siver \& KLING (1997) and LiKhoshWAY \& CRAWFORD (2001). The terms distal and proximal are used in the sense of EDGAR et al. (2004), which means that the collar is the proximal part of the valve mantle, while the valve face is the distal part of the valve.

\section{Results}

Aulacoseira brasiliensis Tremarin, Torgan et T. Ludwig sp. nov. (Figs 2-48)

Diagnose: ab Aulacoseira muzzanensis catenis parvis cum separatio valvae, superficie valvari integre areolata et limbus striis rectis et densior areolato differt. Ab Aulacoseira agassizii pseudosepto depauperato differt, forma spinarum, morphologia et dispositione rimoportulae.

Descriptio: frustula generaliter solitaria aut in catenis parvis 2-3 cellularibus, spinis longis marginalibus, acutis, longitudine differentibus conjuctis. Superficies 
Table 1. Data from sampling sites of Aulacoseira brasiliensis, Brazil, and the Material number at the Herbarium of the Paraná Federal University (UPCB), Herbarium Alarich Schultz (HAS) of the Natural Science Museum - Zoobotanic Foundation, Rio Grande do Sul, Herbarium of the Academy of Natural Sciences of Philadelphia (ANSP GC), Botanic Institute (SP) and Institute of Amazonian Research (INPA).

\begin{tabular}{|c|c|c|c|c|c|}
\hline Locality & State & Coordinates & Date & Sample & Material number \\
\hline Cascavel River & Paraná & $25^{\circ} 23^{\prime} 36^{\prime} \mathrm{S} / 51^{\circ} 27^{\prime} 19^{\prime \prime} \mathrm{W}$ & Oct./2007 & $\begin{array}{l}\text { phyto- } \\
\text { plankton }\end{array}$ & $\begin{array}{l}\text { UPCB } 59502, \text { HAS } \\
6210, \text { GC } 2807\end{array}$ \\
\hline Reflora II Lake & Paraná & $26^{\circ} 19^{\prime} 34^{\prime \prime} \mathrm{S} / 51^{\circ} 22^{\prime} 32^{\prime \prime} \mathrm{W}$ & Feb./2005 & periphyton & UPCB 67015 \\
\hline Maurício River & Paraná & $25^{\circ} 42^{\prime} 59^{\prime \prime} \mathrm{S} / 49^{\circ} 19^{\prime} 28^{\prime \prime} \mathrm{W}$ & May/2006 & periphyton & UPCB 58052 \\
\hline Guaraguaçu River & Paraná & $25^{\circ} 35^{\prime} 31^{\prime \prime} \mathrm{S} / 48^{\circ} 38^{\prime} 23^{\prime \prime} \mathrm{W}$ & Apr./2003 & $\begin{array}{l}\text { phyto- } \\
\text { plankton }\end{array}$ & UPCB 47493 \\
\hline lake & São Paulo & $22^{\circ} 08^{\prime} 02^{\prime \prime} \mathrm{S} / 47^{\circ} 48^{\prime} 17^{\prime} \mathrm{W}$ & May/1990 & $\begin{array}{l}\text { phyto- } \\
\text { plankton }\end{array}$ & SP 188212 \\
\hline Tupé Lake & Amazonas & $3^{\circ} 2^{\prime} 36^{\prime \prime} \mathrm{S} / 60^{\circ} 15^{\prime} 18^{\prime \prime} \mathrm{W}$ & Dec./2003 & $\begin{array}{l}\text { phyto- } \\
\text { plankton }\end{array}$ & INPA 223907 \\
\hline Água Preta Lake & Pará & $1^{\circ} 25^{\prime} 35^{\prime \prime} \mathrm{S} / 48^{\circ} 24^{\prime} 54^{\prime \prime} \mathrm{W}$ & Aug./2007 & $\begin{array}{l}\text { phyto- } \\
\text { plankton }\end{array}$ & UPCB 72036 \\
\hline $\begin{array}{l}\text { Sinhá Mariana } \\
\text { Lake }\end{array}$ & $\begin{array}{l}\text { Mato } \\
\text { Grosso }\end{array}$ & $16^{\circ} 19^{\prime} 51^{\prime \prime} \mathrm{S} / 55^{\circ} 53^{\prime} 22^{\prime \prime} \mathrm{W}$ & $\begin{array}{l}\text { Sep./1997 } \\
\text { to } \\
\text { Aug./1998 }\end{array}$ & $\begin{array}{l}\text { phyto- } \\
\text { plankton }\end{array}$ & $\begin{array}{l}\text { UPCB } 67019 \text {, HAS } \\
6211\end{array}$ \\
\hline
\end{tabular}

valvaris plana integre areolata. Limbus striis rectis ex areolas rotundatas compositis. Sulcus et pseudosulcus parum prominentes. Pseudoseptum depauperatum. Duae series rimoportularum, alia prope superficiem valvarem, alia prope collum. Rimoportulae sessiles quincuncialiter dispositis.

Diagnosis: Aulacoseira brasiliensis differs from A. muzzanensis by forming shorter chains with only separation valves, by the completely areolated valve face, by the valve mantle having straight striae and higher density of areolae; and from $A$. agassizii by recessed ringleist, spines shape and rimoportulae morphology and organization.

Description (LM): cells cylindrical with parietal small discoid chloroplasts (Fig. 2), frustules often solitary or forming short chains with two to three cells joined by marginal acute separation spines of different sizes. Valve surface flat, $8-24 \mu \mathrm{m}$ in diameter, completely areolated (Figs 3-5). Valve mantle square to rectangular in cross-section, 4-10 $\mu \mathrm{m}$ in height, ratio height mantle/diameter $0.20-0.88 \quad(n=244)$ (Table 2). The valve mantle ornamented by straight pervalvar rows of striae, 10-16 in $10 \mu \mathrm{m}$, composed of not equidistant circular areolae, $10-15$ in $10 \mu \mathrm{m}$ (Figs 8-30). Collar weakly developed and pseudosulcus in V-shaped (Fig. 17). Ringleist narrow (Figs 6-7). Rimoportulae inconspicuous.

Holotype: UPCB collection No. 59502 (Paraná
Federal University, Botany Department, Brazil). Isotypes: ANSP GC 26807 (Academy of Natural Sciences, Philadelphia), slide $n^{\circ} 6210$ (Herbarium Prof. Dr. Alarich Schultz, Natural Science Museum - Zoobotanic Foundation, Rio Grande do Sul).

Type locality: Cascavel River, Guarapuava municipality, Paraná State, Brazil (phytoplankton, coll. date 25/10/2007, collector L.L. WoLFF).

Etymology: the epithet "brasiliensis" was chosen because the species have been found in Brazilian waters.

Material examined: reflora II Lake, São Pedro Farm, General Carneiro municipality, Paraná State, Brazil, 02/2005, UPCB 67015; Maurício River, Fazenda Rio Grande municipality, Paraná State, Brazil, 08/04/2006, UPCB 58051; Guaraguaçu River, Pontal do Paraná municipality, Paraná State, 16/04/2003, UPCB 47493; lake in SP-310, km 220, São Paulo State, Brazil, 08/04/1990, SP 188212; Tupé Lake, Amazonas State, Brazil, 13/12/2003, INPA 223907; Água Preta lake, Pará State, Brazil, 29/08/2007, UPCB 72036; Sinhá Mariana Lake, Mato Grosso State, Brazil, Sep.1997-Aug.1998, UPCB 67019, HAS 6211.

Electron Microscopy (SEM and TEM): externally, the valve face is flat, with randomly 


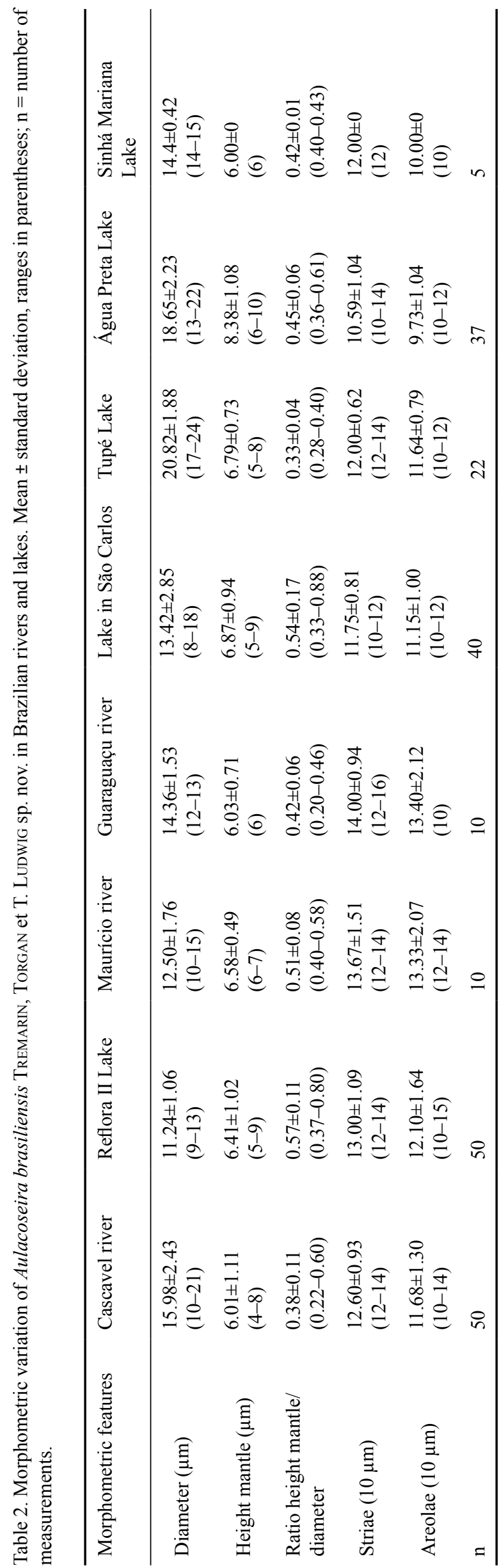

arranged rounded areolae (Figs 31, 32) occluded by a delicate velum of vola-type (Figs 33-34). In the valve mantle, the areolae can be more or less rounded to elliptical, arranged in straight pervalvar rows (Fig. 36). The unevenly long marginal spines have ovate shape with attenuated apices, usually 4-7 $\mu \mathrm{m}$ in length (Figs 36-38). They are externally supported with several short trabeculae at the base (Fig. 37). Between two spines there are two to three rows of areolae, now and there a row of areolae can run up to the base of a spine (Figs $35,36)$. Several conical grooves for insertion of longer spines of the sibling valve are present on the valve mantle at the valve face circumference (Fig. 36). The structureless collar is milled with short pervalvar wrinkles at the proximal end (Figs 39, 41) and bordered by a row of coarser areolae at the distal end. Rimoportulae are arranged in two rings on the valve mantle, one ring is located near the valve face/valve mantle junction and the other at the ringleist (Figs 39, 41, 44, 45). Elliptical outer apertures of rimoportulae oriented pervalvary can be observed between the marginal spines or near the base of these (Figs 39, 40). The narrow slitlike outer apertures of rimoportulae situated at the ringleist are oriented circumferentially (Fig. 41). Internally, the rimoportulae are small, sessile and are located at every sixth or more row of areolae, taking the place of an areola (Figs 44, 45). The rimoportulae slits are pervalvary oriented in the ring near the valve face and circumferentially oriented in the ring at the ringleist, arranged in zigzag (Fig. 44). Some valve mantles may have a "Müller Step" (sensu MüLLER 1884 and CRAWFORD \& LikHoshway 1999) (Figs 31, 35). Internally, the valve has a solid and undeveloped ringleist (Figs 42-44). The cingulum is composed of 5-10 open bands (Fig. 46) ornamented by small rounded pores (Figs 47-48). Ligule proeminent and antiligule less evident (Figs 47-48).

\section{Discussion}

Aulacoseira brasiliensis is characterized mainly by short filaments, ovate-attenuate spines, a narrow ringleist and two rows of rimoportulae zigzag arranged. Moreover, the orientation of the external and internal slits of the rimoportulae is different between the two rows (Figs 40-41). The presence of double row of rimoportulae is unique in the genus.

The new species is similar to separation valves of 
A. muzzanensis (Meister) Krammer (Figs 49-65) by the frustules rectangular in girdle view, weakly developed ringleist and long separation spines (Fig. 56). However, A. muzzanensis forms long chains, its valves with linking spines have spiral dextrorse rows of areolae on the valve mantle (Figs 54-59), valve faces with areolae situated only next to the edges (Figs 50-53), a ring of elongated and curved rimoportulae (Fig. 55) close to the ringleist (Figs 62-65), and the valve mantle with higher density of quadrangular areolae (HustedT 1930; KRAMMER 1991) (Table 3).

Although $A$. muzzanensis possess valves with separation and linking spines, the heterovalvarity was not always observed. Filaments formed exclusively by linking spines were reported by Meister (1912), when the species was proposed.

The heterovalvarity was not found in $A$. brasiliensis, and no filaments were found with linking spines. Most of the chains observed by SEM showed their intermediate cells covered by cingulum bands, which prevented the visualization of the cells link region. In addition, exemplars were usually isolated and the formation of chains was only observed in samples with high density of individuals. We believe that there are no linking spines in A. brasiliensis, as in other species of the genus [e.g. A. herzogii (Lemmerman) Simonsen, A. pusilla (Meister) Tuj et Williams, $A$. tenella (NygaARd) Simonsen].

Another similar species to A. brasiliensis is A. agassizii (Ostenfeld) Simonsen var. agassizii (Figs 66-88) by the areolation pattern of the valve face and presence of elongated separation spines. However, the latter possess a wide ringleist (Figs $71,72,86)$, straight pervalvar rows of areolae on the separation valve (Figs 73, 79, 80), obliquecurved rows of areolae on the linking valve (Figs 75-78, 81) and lower striae density. In addition, A. agassizii var. agassizii has an irregular ring of rimoportulae situated near the ringleist (Figs 8488), slightly stalked shaped rimoportulae, oriented tangentially or radially to the valve margin (Figs 86-88).

KrAMMER (1991) comments that A. agassizii var. agassizii may have filaments composed of separation and linking valves, or only one of these. The few images in SEM presented in the literature illustrate only the separation spines (Crawford 1979, 1980). The morphology of linking spines has never been presented before and so our SEM pictures of them (Figs 81-83) are the first published ones. Another fact not documented before is the different areolation pattern of the valve face of this species. The separation valves exhibit the valve face to be completely or partially areolated (Figs 66-69, 79), and the linking valves shows only marginal areolation (Fig. 70).

Among all the species of the genus, $A$. agassizii var. malayensis (HustedT) SimONSEN (Figs 89-112) is the most similar to A. brasiliensis, mainly by the completely areolated valve face (Figs 90-92, 101, 104), by the straight striation pattern in the mantle (Figs 93-100, 104, 105) and by forming short filaments exclusively consisted of separation valves (Figs 93-100). The particular characteristics of this species are wide ringleist (Figs 89, 107), lower density of striae and areolae closer to each other, just as illustrated by HUSTEDT (1942, fig. 458 a, f-h) when proposed the species. The sessile rimoportulae are arranged in an irregular ring around the ringleist (Figs 108-110) also differ from those of $A$. brasiliensis which are in alternating double rows, however, in both of them they are located in the place of one of the areolae (Fig. 44) in A. brasiliensis, or inside an areola (Fig. 109) in A. agassizii var. malayensis. HustedT (1942) distinguished A. agassizii var. malayensis from the nominal variety by the presence of a lower striae density $(8-10$ in $10 \mu \mathrm{m})$ and by the more developed ringleist. Furthermore, after examining the ultrastructure of var. malayensis, we found that the creation of frustules with thicker cell walls and the position and morphology of rimoportulae also distinguished this variety.

Another fact that differentiates $A$. brasiliensis from other species is the ovate-attenuated form of the separation spines that have longitudinal thickening at their base (Figs 86, 87). In $A$. muzzanensis, A. agassizii and A. agassizii var. malayensis the spines are pointed and each second or third row of the valve mantle areolae runs to the base of a spine (Figs 56, 79, 80, 104, 105). This can be clearly seen in the illustrations of Crawford (1979, pl. 2, fig. 8) or Krammer (1991, pl. 2, figs 10, 11, pl. 4, figs 17, 17a). Furthermore, A. brasiliensis has no small conical spines among the long spines as in the species cited above. In $A$. agassizii linking spines are spatulated and very close to each other, often with apiculate apices and irregular margins (Figs 82, 83), and in $A$. muzzanensis they are spatula shaped, cut-out on tops and not so close arranged (Figs 60, 61).

The analysis of the ultrastructure of $A$. agassizii var. malayensis is unprecedented. 


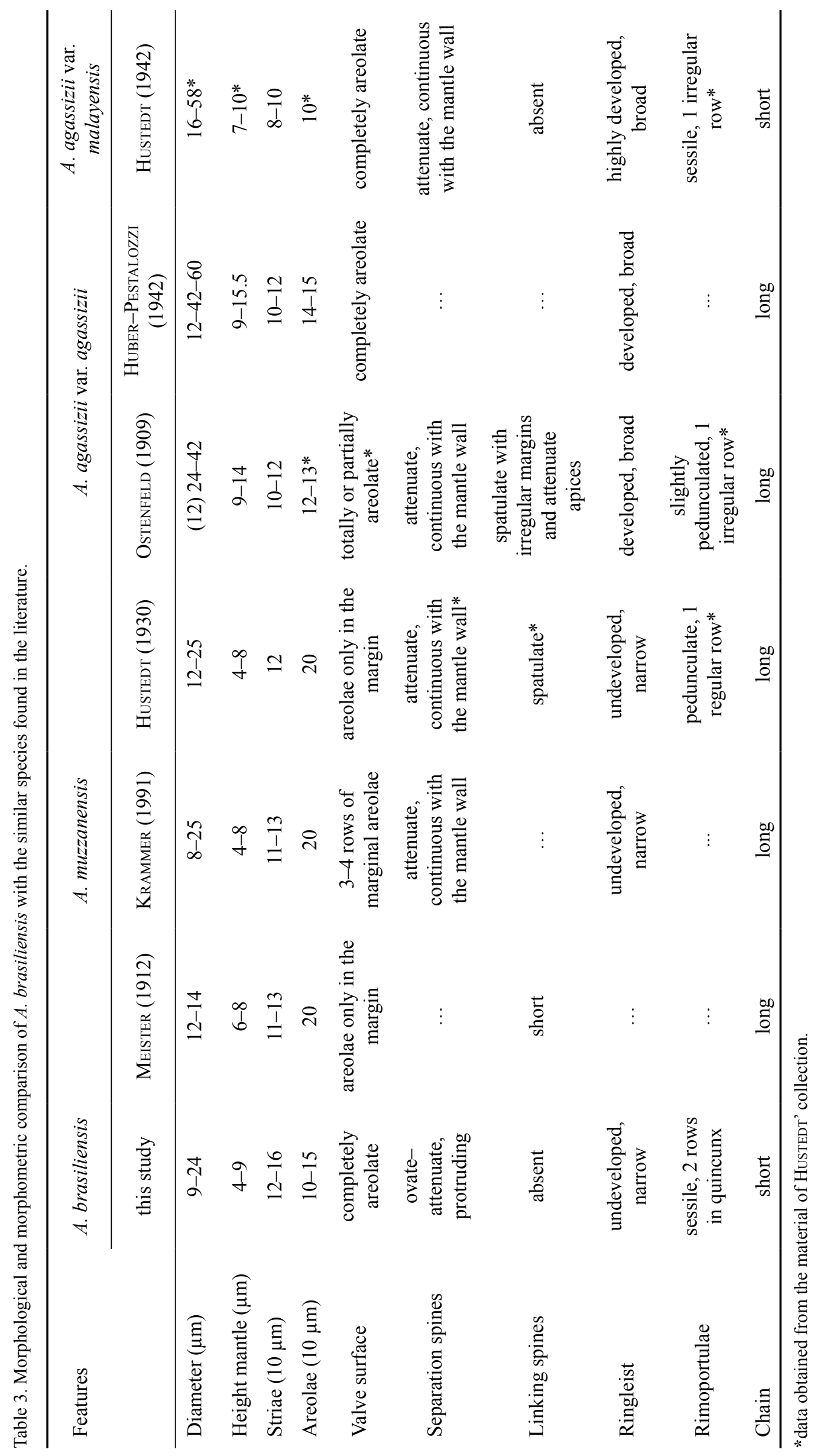


Specimens of A. muzzanensis and A. agassizii had their morphology analyzed by other researchers [e.g. Crawford (1979, 1980); Stoermer \& ANDRESEn (1990); Krammer (1991); Fourtanier et al. (1993)]. However, the shape, number and position of rimoportulae of these species were not so far recorded in the literature.

Aulacoseira brasiliensis was found in tropical and subtropical regions of Brazil. The populations studied in these sites were similar with respect to morphological characteristics of the valve. However, we found larger specimens in Tupé lake (diameter up to $24 \mu \mathrm{m}$ ) than in other locations (Reflora II lake, Maurício river, Guaraguaçu river and Sinhá Mariana lake) where the valve diameter did not exceed $15 \mu \mathrm{m}$ (Table 2).

Higher densities of Aulacoseira brasiliensis were found in Cascavel river, Reflora II lake and in a lake from São Paulo. High temperatures $\left(21.3-29.9{ }^{\circ} \mathrm{C}\right)$, acid to neutral conditions ( $\mathrm{pH}$ $5.5-7.7)$, low conductivity $\left(6.3-26 \mu \mathrm{S} . \mathrm{cm}^{-1}\right)$, high BOD (2.5-4.8 $\left.\mathrm{mgO}_{2} \cdot 1^{-1}\right)$ and high COD (8.1-45.1 $\left.\mathrm{mgO}_{2} \cdot 1^{-1}\right)$ characterize the Cascavel river and Tupé lake (Peres et al. 2008; Pereira 2009). Low density populations occurred in eutrophic waters (Sinhá Mariana lake and Itaqui lake) with relatively high temperatures $\left(20.8-37^{\circ} \mathrm{C}\right)$, lower $\mathrm{pH}$ (5.5-5.9), high BOD (3.6 $\left.\mathrm{mgO}_{2} \cdot 1^{-1}\right)$ and high COD $\left(12 \mathrm{mgO}_{2} .^{-1}\right)$ (Loverde-Oliveira \& Huszar 2007; FARIA 2010). Although environmental data can be obtained from Loverde-Oliveira \& Huszar (2007), Peres et al. (2008); Pereira (2009) and FARIA (2010).

Specimens of $A$. brasiliensis had been previously found by other Brazilian researchers in lotic and lentic environments, but with mislead identification. The first record was from BRASSAC et al. (1999), determining the taxon as A. agassizii. Then, Visinoni (2002), Morandi (2008) and FARIA (2010) cited the species as A. muzzanensis. The populations studied by these authors were similar to those described in this work, either in morphology as in valve sizes.

Since the metric variation of $A$. brasiliensis overlapped with that of other Aulacoseira species, the observation of the chains and the valve ultrastructure is recommend for a precise taxonomic determination.

\section{Acknowledgements}

To CAPES (Coordenação de Aperfeiçoamento de Pessoal de Nível Superior) for doctoral Grant to the first author; to CNPq (Conselho Nacional de Desenvolvimento Científico e Tecnológico) for the scientific productivity Grants to the second and third authors; to Dr. Friedel Hinz (Alfred Wegener Institut für Polar- und Meeresforschung); to Dra. Simoni M. Loverde-Oliveira, Dr. Rosildo S. Paiva and Msc. Andreia C. Pereira, for supplying samples and data for the study; to Dr. William Rodrigues and Msc. Kaoli Cavalcante for the help with Latin; and to Electron Microscopical Center of the Paraná Federal University by technical assistance.

\section{References}

Bicudo, C.E.M. \& Menezes, M. (2006): Gêneros de algas de águas continentais do Brasil. - 498 pp., Rima, São Paulo.

Brassac, N.M.; Atab, D.R.; Landucci, M.; Visinoni, N.D. \& Ludwig, T.A.V. (1999): Diatomáceas cêntricas de rios na região de abrangência da Usina Hidrelétrica de Salto Caxias, PR (Bacia do Rio Iguaçu). - Acta Botânica Brasilica 13: 277-289.

Crawford, R.M. (1979): Filament formation in the diatom genera Melosira C.A. Agardh and Paralia Heiberg. Beih. - Nova Hedwigia 64: 121-133.

Crawford, R.M. (1980): Suggested criteria for the reclassification of the diatom genus Melosira C. Agardh. - In: DesiKachary, T.V. \& RaO, V.N.R. (eds): Taxonomy of algae. - pp. 671-681, University of Madras.

Crawford, R. M. \& Likhoshway, Y. (1999): The frustule structure of original material of Aulacoseira distans (Ehrenberg) Simonsen. - Diatom Research, 14: 239250.

Denys, L.; Muylaert, K.; Krammer, K.; Joosten, T.; Reid, M. \& Rioual, P. (2003): Aulacoseira subborealis stat. nov. (Bacillariophyceae): a common but neglected plankton diatom. - Nova Hedwigia 77: 407-427.

Edgar, S.M. \& Theriot, E.C. (2003): Heritability of mantle areolar characters in Aulacoseira subartica (Bacillariophyta). - Journal of Phycology 39: 10571066.

Edgar, S.M. \& Theriot, E.C. (2004): Phylogeny of Aulacoseira (Bacillariophyta) based on molecules and morphology. - Journal of Phycology 40: 772788.

Edgar, R.K.; Kociolek, J.P. \& Edgar, S.M. (2004): Life cycle-associated character variation in Aulacoseira krammeri sp. nov., a new Miocene species from Oregon, U.S.A. - Diatom Research, 19: 7-32.

FARIA,D.M.(2010):Diatomáceas perifíticas deumreservatório eutrófico do rio Itaqui: aspectos qualitativos e quantitativos [Dissertação de Mestrado]. - 152 pp., Universidade Federal do Paraná, Curitiba.

Fourtanier, E.; Gasse, F.; Bellier, O.; Bonhomme, M.G. \& Robles, I. (1993): Miocene non-marine diatoms from the western cordillera basins of northern Peru. - Diatom Research 8: 13-30.

Hickel, B. \& HÅkansson, H. (1991): The freshwater diatom 
Aulacoseira herzogii. - Diatom Research 6: 299305.

Houk, V. (2003): Atlas of freshwater centric diatoms with a brief key and descriptions. Part 1. Melosiraceae, Orthoseiraceae, Paraliaceae and Aulacoseiraceae. Czech Phycology Supplement 1: 1-112.

Houk, V. \& KLEe, R. (2007): Atlas of freshwater centric diatoms with a brief key and descriptions. Part II. Melosiraceae and Aulacoseiraceae (Supplement to Part I). - Fottea 7: 85-25.

Huber-Pestalozzi, G. (1942): Diatomeen. - In: Thienimann, A. (ed.): Das Phytoplankton des Susswassers, Systematik und Biologie 2. - pp. 367-549, Stuttgart, E. Schweizerbartsche Verlagsbuchhandlung.

Hustedt, F. (1930): Bacillariophyta (Diatomeae). - In: Pascher,A.(ed.): Die Süsswasser-Flora Mitteleuropas 10. -466 pp., G. Fischer, Jena.

Hustedt, F. (1942): Süßwasser-Diatomeen des indomalayischen Archipels und der Hawaii-Inslen. - Internationale Revue der Gesamten Hydrobiologie und Hydrographie 42: 1-252.

Krammer, K. (1991): Morphology and taxonomy in some taxa of the genus Aulacoseira Thwaites (Bacillariophyceae) II. Taxa in the A. granulata-, italica- and lirata-groups. - Nova Hedwigia 53: 477-496.

LiKHOSHWAY, Y.V. \& CRAwFord, R.M. (2001): The rimoportula - a neglected feature in the systematics of Aulacoseira. - In: Economou-Amilli, A. (ed.): Proceedings of the $16^{\text {th }}$ International Diatom Symposium 2000. - pp. 33-47, Amvrosiou Press, Greece.

Loverde-Oliveira, S.M. \& Huszar, V.L.M. (2007): Phytoplankton ecological responses to the flood pulse in a Pantanal lake, Central Brazil. - Acta Limnologica Brasiliensia 19: 117-130.

MeIster, F. (1912): Die Kieselalgen der Schweiz. - Beiträge zur Kryptogamenflora der Schweiz 4: 1-254.

Morandi,L.L.(2008): Coscinodiscophyceae(Bacillariophyta) de águas continentais do estado de São Paulo: diversidade florística [Dissertação de Mestrado]. 135 pp., Universidade de São Paulo.

Moreira-Filho, H. \& Valente-Moreira, I.M. (1981): Avaliação taxonômica e ecológica das diatomáceas (Bacillariophyceae) epífitas em algas pluricelulares obtidas nos litorais dos estados do Paraná, Santa Catarina e São Paulo. - Boletim do Museu Botânico Municipal 47: 1-17.

Moro, R.S. (1991): Morphology of Aulacoseira granulata (Ehr.) Simonsen var. australiensis (Grunow) nov. comb. under light microscopy. - Arquivos de Biologia e Tecnologia 34: 353-359.

Müller, O. (1884): Die Zellhaut und das Gesetz der Zelltheilungsfolge von Melosira arenaria Moore. Jahrbücher für wissenschaftliche Botanik, Band XIV, H 2: 232-290.

Ostenfeld, C.H. (1909): Notes on the Phytoplankton of Victoria Nyanza, East Africa. - Bulletin of the Museum of Comparative Zoology at Harvard College 52: $171-181$.

Pereira, A.C. (2009): Pinnulariaceae (Bacillariophyta) de um lago de inundação amazônico (lago Tupé, Amazonas, Brasil): taxonomia e distribuição espacial e sazonal [Dissertação de Mestrado]. - 88 pp. Instituto de Pesquisas da Amazônia/INPA.
Peres, K.K.; Peres, C.K.; KrupeK, R.A. \& Branco, C.C.Z. (2008): Diagnóstico da qualidade da água do rio Cascavel, município de Guarapuava, Estado do Paraná. - Ambiência 4: 25-35.

Potapova, M.G.; Bixby, R.J.; Charles, D.F.; Edlund, M.B.; Enache, M.E.; Furey, P.; Hamilton, P.B.; Lowe, R.L.; Manoylov, K.M.; Ognjanova-Rumenova, N.; Ponader, K.C.; Ren, L.; Siver, P.A.; Spaulding, S.A. \& ZaLaCK, J. (2008): Eighteenth NAWQA Workshop on Harmonization of Algal Taxonomy Representatives of the genus Aulacoseira Thwaites in NAWQA samples. Report No. 08-07. - 56 pp., PCER, ANSP, Philadelphia, PA.

Raupp, S.V.; Torgan, L.C. \& Baptista, L.R.M. (2006): Composição e variação temporal de diatomáceas (Bacillariophyta) no plâncton da represa de Canastra, sul do Brasil. - Iheringia 61: 105-134.

Round, F.E.; Crawford, R.M. \& Mann, D.G. (1990): The diatoms: biology and morphology of the genera. 747 pp., Cambridge University Press, New York.

SiMONSEN, R. (1974): The diatom plankton of the Indian Ocean Expedition of R/V "Meteor" 1964-1965. - "Meteor" Forsch.-Ergebnisse Reihe D-Biol. 19: 1-66.

Siver, P.A. \& KLING, H. (1997): Morphological observations of Aulacoseira using scanning electron microscopy. - Canadian Journal of Botany 75: 1807-1835.

SourniA , A. (1978): Phytoplankton manual. - Monographs an Oceanographie Methodology 6: 1-337.

Stoermer, E.F. \& Andresen, N.A. (1990): Aulacoseira agassizii in North America. - Nova Hedwigia 100: 217-223.

Tremarin, P.I.; Loverde-Oliveira, S.M.; Ludwig, T.A.V. \& TORGAN, L.C. (2011): Ultrastructure and distribution of Aaulacoseira gessneri (Hustedt) Simonsen (Diatomeae). - Diatom Research 26: 189-197.

Tus,, A. \& Houk, A. (2004): Taxonomy, ultrastructure and biogeography of the Aulacoseira subarctica species complex. - Bulletin of the National Science Museum. Series B, (Bot.) 30: 35-55.

Visinoni, N.D. (2002): Diatomáceas de rios da região metropolitana de Curitiba, Paraná, Brasil: Coscinodiscophyceae, Fragilariophyceae e Bacillariophyceae (Achnanthales e Bacillariales) [Dissertação de Mestrado]. - 133 pp. Universidade Federal do Paraná, Curitiba. 

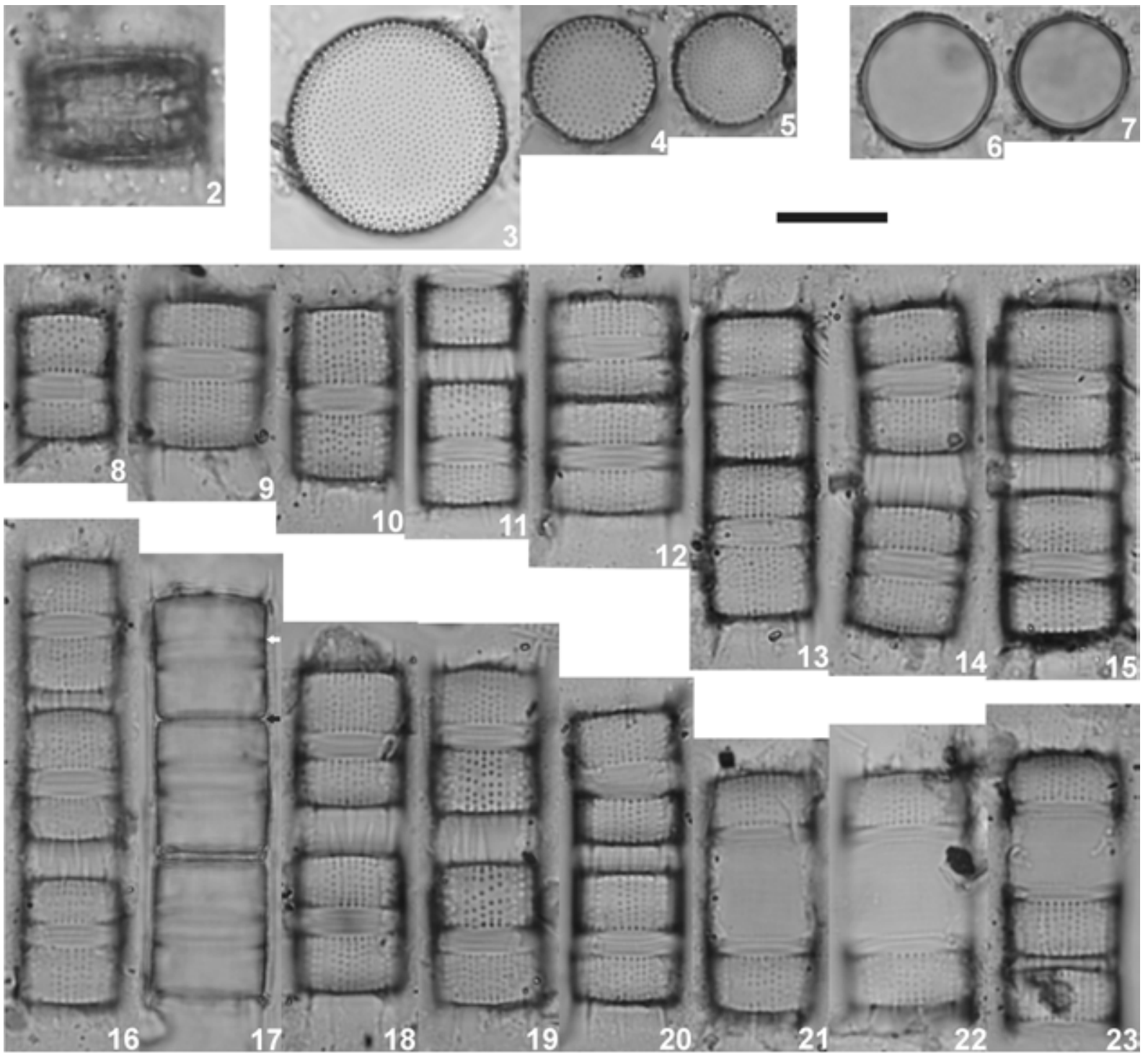

10
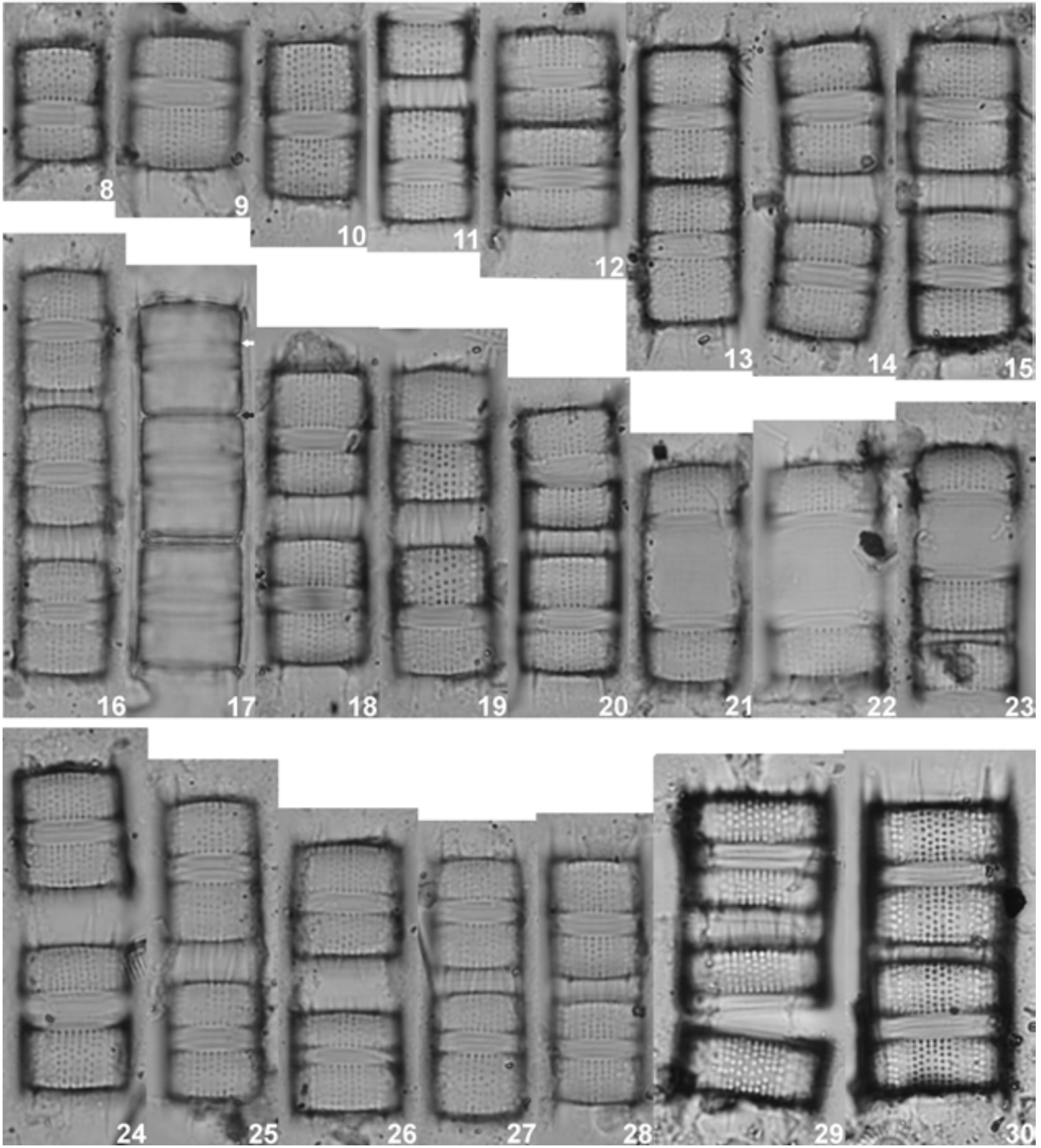

Figs 2-30. Aulacoseira brasiliensis, LM: (2-15) Cascavel River, Paraná, Brazil, holotype UPCB 59502, (2) frustules with small discoid chloroplast, (3-5) valve view, (6-7) ringleist narrow, (8-15) frustules in pleural view; (16-28) Reflora II Lake, Paraná, Brazil, UPCB 67015, (16-28) frustules in pleural view, (17) shallow collar (white arrow) and V-shaped pseudosulcus (black arrow), (21-23) frustules with cingulum; (29-30) Guaraguaçu River, Paraná, Brazil, UPCB 47493, frustules in pleural view. Scale bar $10 \mu \mathrm{m}$. 

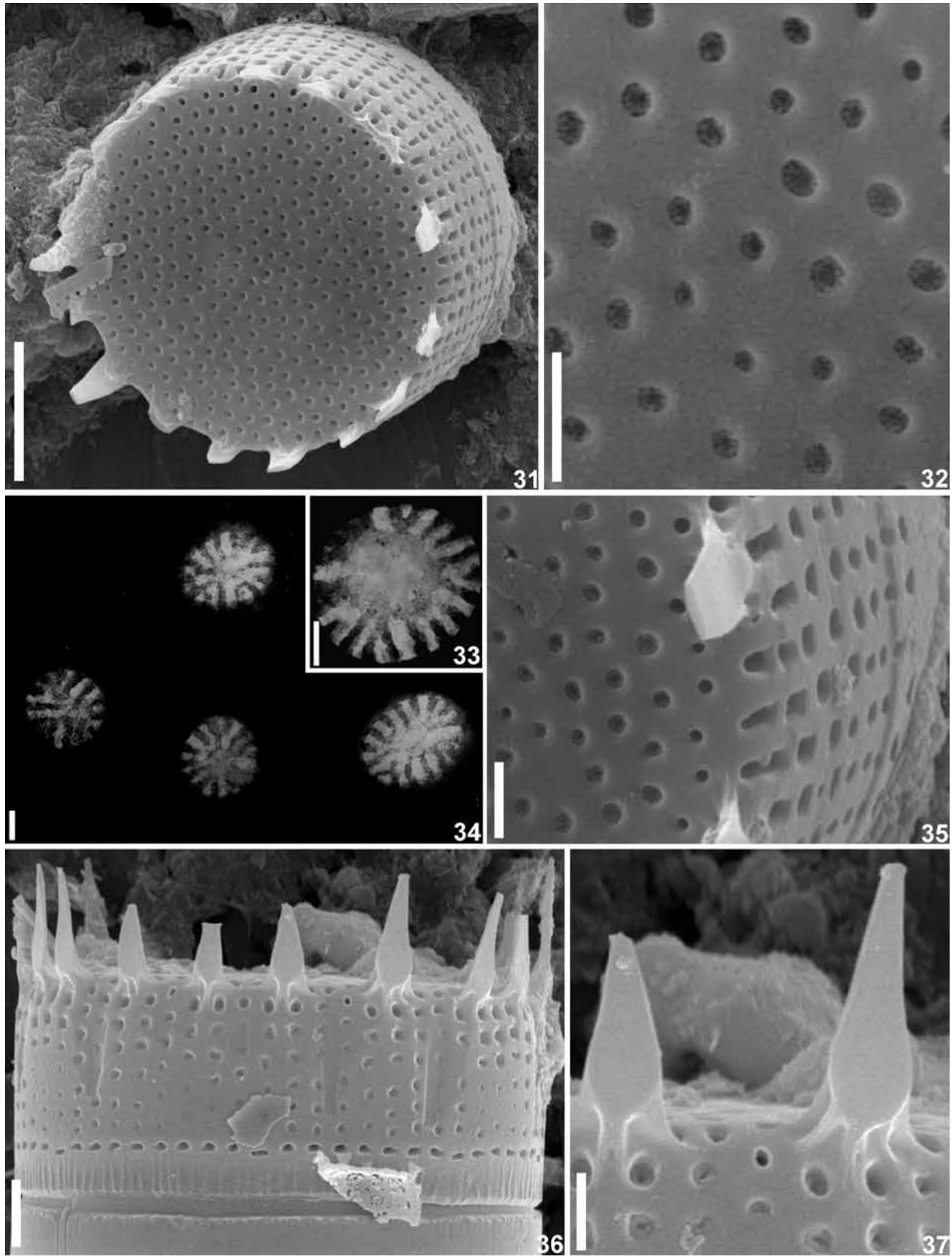

Figs 31-37. External view of Aulacoseira brasiliensis (Cascavel River, Paraná, Brazil, stub UPCB 59502-01S, prepared from type material), SEM and TEM: (31) valve view showing the flat valve face and "Müller Step" in the mantle; (32) detail of the areola in the valve face; (33-34) areola occlusion; (35) view of the valve face/valve mantle junction with marginal spines; (36) pleural view. Note the tapered marginal spines and the mantle depressions. (37) detail of the marginal spines. Scale bars $5 \mu \mathrm{m}$ (31), $1 \mu \mathrm{m}(32,36,37), 2 \mu \mathrm{m}$ (35), $100 \mathrm{~nm}(33-34)$. 

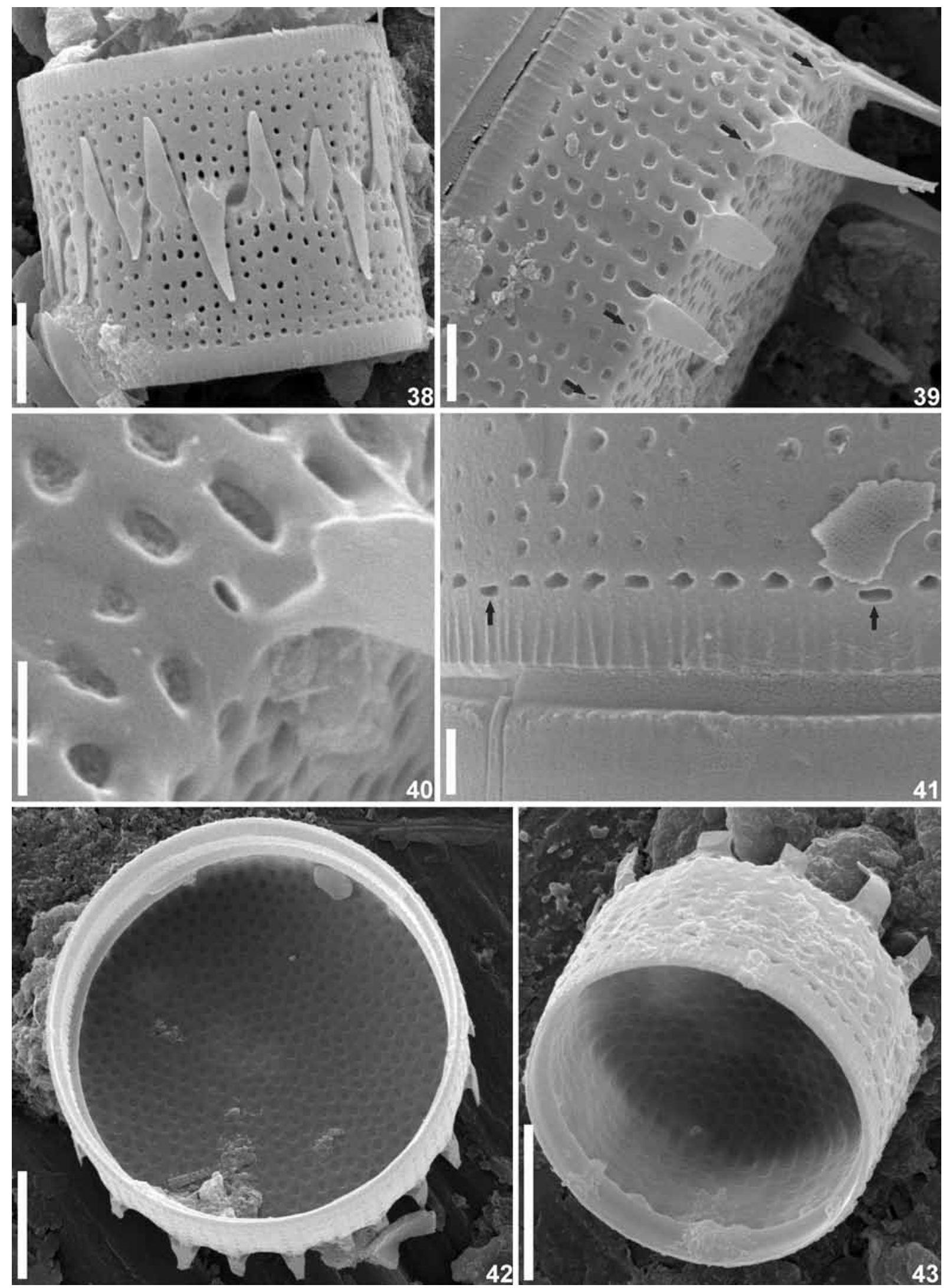

Fig. 38-43. Aulacoseira brasiliensis (Cascavel River, Paraná, Brazil, stub UPCB 59502-01S, prepared from type material), SEM: (38) sibling valves with long separation spines; (39) external openings of rimoportulae (arrows) in the valve face/valve mantle junction; (40) detail of the rimoportula opening; (41) mantle view, rimoportulae openings at the collum (arrows); (42-43) overview of valve. Scale bars $5 \mu \mathrm{m}(38,42,43), 2 \mu \mathrm{m}(39), 1 \mu \mathrm{m}(40,41)$. 

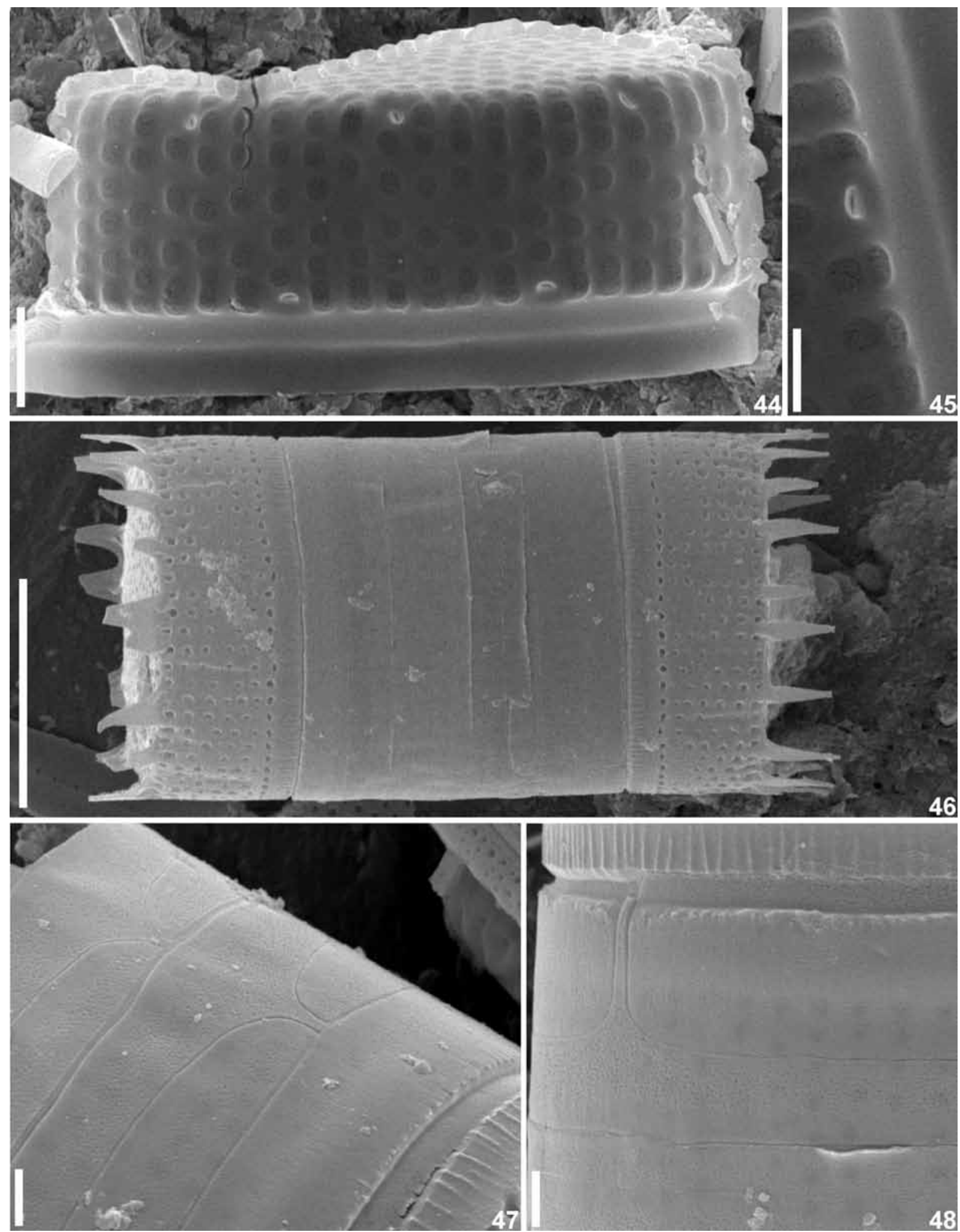

Fig. 44-48. Aulacoseira brasiliensis (Cascavel River, Paraná, Brazil, stub UPCB 59502-01S, prepared from type material), SEM: (44) internal view of valve showing the rimportulae arranged in quincunx. Note the solid and undeveloped ringleist; (45) detail of the rimoportula opening at the ringleist; (46) external view of the frustule showing the cingulum bands; (47-48) detail of the bands showing the ligulae and the ornamentation of small porous. Scale bar $5 \mu \mathrm{m}(44), 1 \mu \mathrm{m}(45,47,48), 10 \mu \mathrm{m}(46)$. 


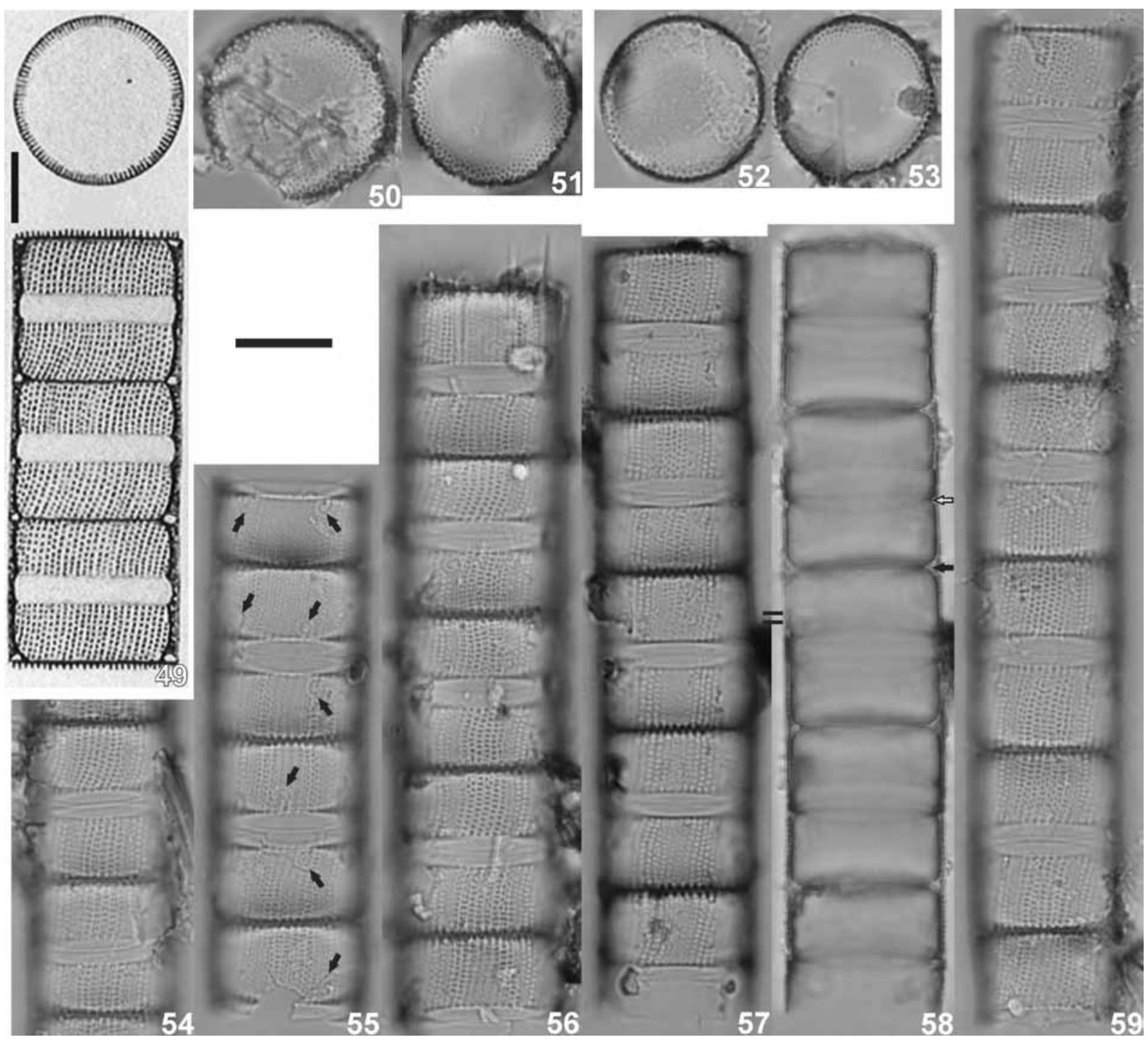

Figs 49-59. Melosira granulata var. muzzanensis (=Aulacoseira muzzanensis), LM: (49) copy of Hustedt drawing of 'Melosira granulata var. muzzanensis (Meister) Hustedt (1930, fig. 10)'; (50-59) material E1289, Lago di Muzzano, Italy, Hustedt Coll, (50-51) view of separation valve, (52-53) view of linking valve, (54-59) pleural view, (55) detail of rimoportulae in the valve mantle (arrows), (56) filament containing terminal cell with separating spines, (58) note the V-shaped collar (white arrow) and U-shaped pseudosulcus (black arrow). Scale bar $10 \mu \mathrm{m}$. 

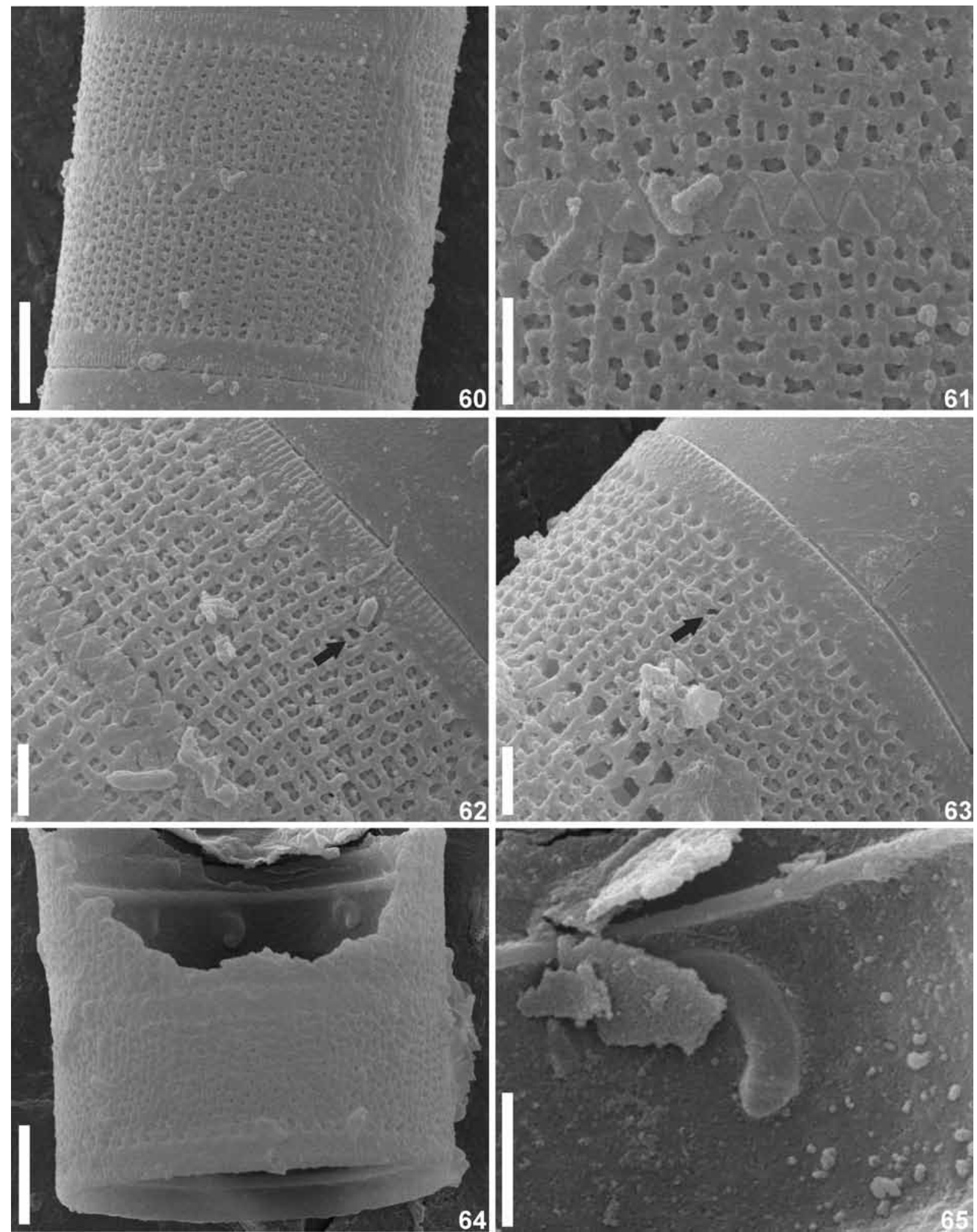

Figs 60-65. Melosira granulata var. muzzanensis (Lago di Muzzano, Italy, stub E1289-01S), SEM: (60) frustule in pleural view; (61) detail of linking spines and areolae; (62-63) external opening of rimoportula (arrows), uni- and bisseriate mantle striae and ornamentation of the collum; (64) broken valve interior showing the internal openings of rimoportulae located near the ringleist; (65) long curved rimoportula projection. Scale bar $5 \mu \mathrm{m}(67,71), 2 \mu \mathrm{m}(68,69,70,72)$. 

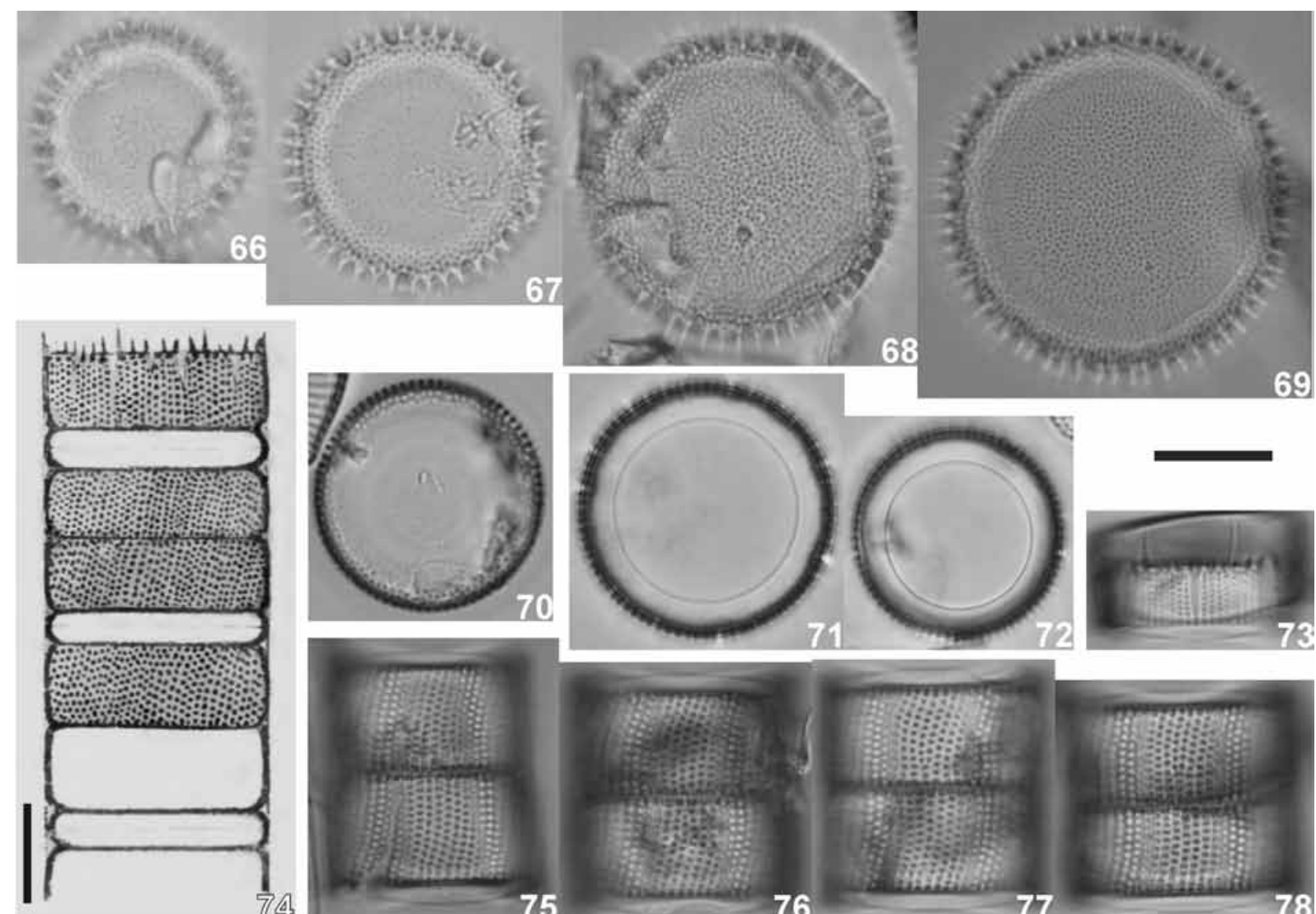

69
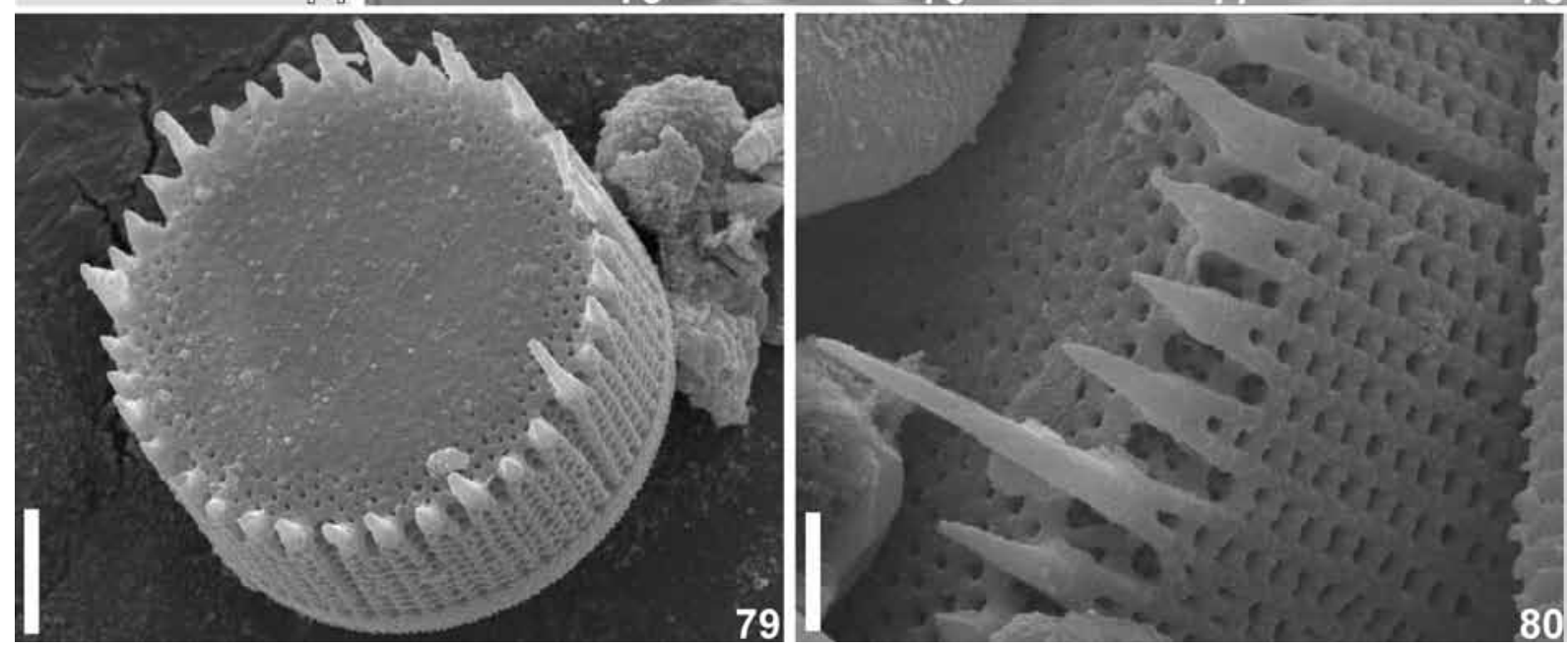

Figs 66-78. Melosira agassizii (=Aulacoseira agassizii), LM: (73-76) material A42, Lake Victoria, South Africa, HuSTEDT Coll; (66-69) valve view of terminal cell; (70) valve view of intermediate cell; (71-72) ringleist wide; (73) separation valve with pointed spines; (74) copy of Ostenfeld drawing of 'Melosira agassizii Ostenfeld (1908, fig. 18)'; (75-78) pleural view of the linking valves with short spines.

Figs 79-80. External view Melosira agassizii (Lake Victoria, South Africa, A42-01S), SEM: (79) view of the separation valve; (80) detail of marginal areolae and separating spines. Scale bar $10 \mu \mathrm{m}(66-78), 5 \mu \mathrm{m}(79), 2 \mu \mathrm{m}(80)$. 

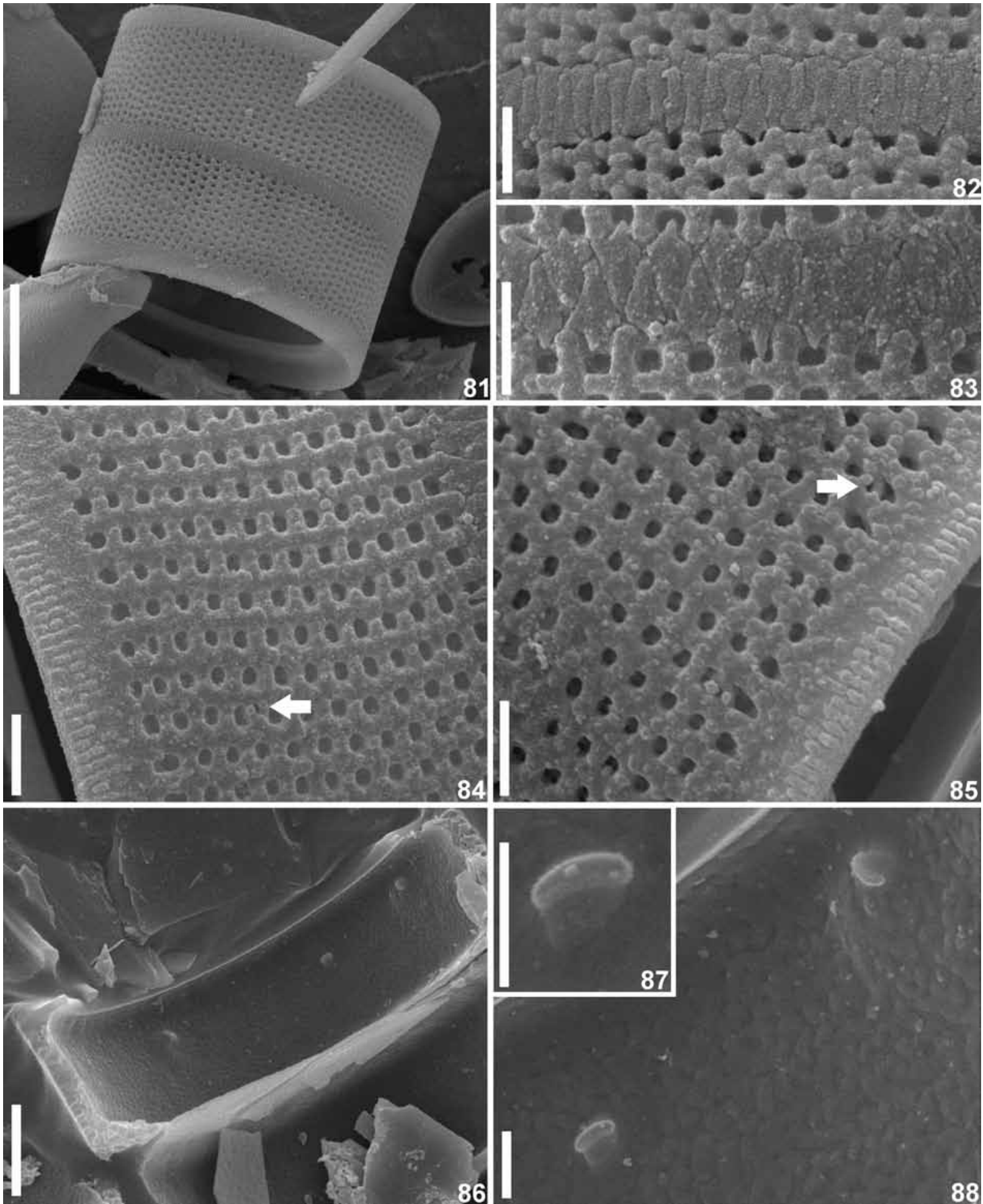

Figs 81-88. External view Melosira agassizii (Lake Victoria, South Africa, A42-01S), SEM: (81) overview of linking valve; (82-83) detail of linking spines; (84-85) external opening of rimoportula (arrows). Note the rounded areolae and ornamentation of collum. $(86,88)$ internal opening of rimoportula, velum of the areolae and solid ringleist; (87) detail of rimoportula opening. Scale bars $10 \mu \mathrm{m}(81), 5 \mu \mathrm{m}(86), 2 \mu \mathrm{m}(82-85), 1 \mu \mathrm{m}(87,88)$.

Figs 89-100. Melosira agassizii var. malayensis (=Aulacoseira agassizii var. malayensis). Material to the lectotype AS1325, Celebes, Malay Archipelago, Lake Posse, Hustedt Coll., LM: (89) ringleist wide; (90-92) valve view; (93-100) pleural view of separation valves. Frustules with thicker cells walls.

Figs 101-105. Melosira agassizii var. malayensis (Celebes, Malay Arch., stub AS1325-01S), SEM: (101) external view of valve; (102-103) details of marginal areolae and separating spines; (104-105) aspect of marginal spines and striation pattern of the mantle. Scale bars $10 \mu \mathrm{m}(89-101,105), 5 \mu \mathrm{m}(102,104), 2 \mu \mathrm{m}(103)$. 

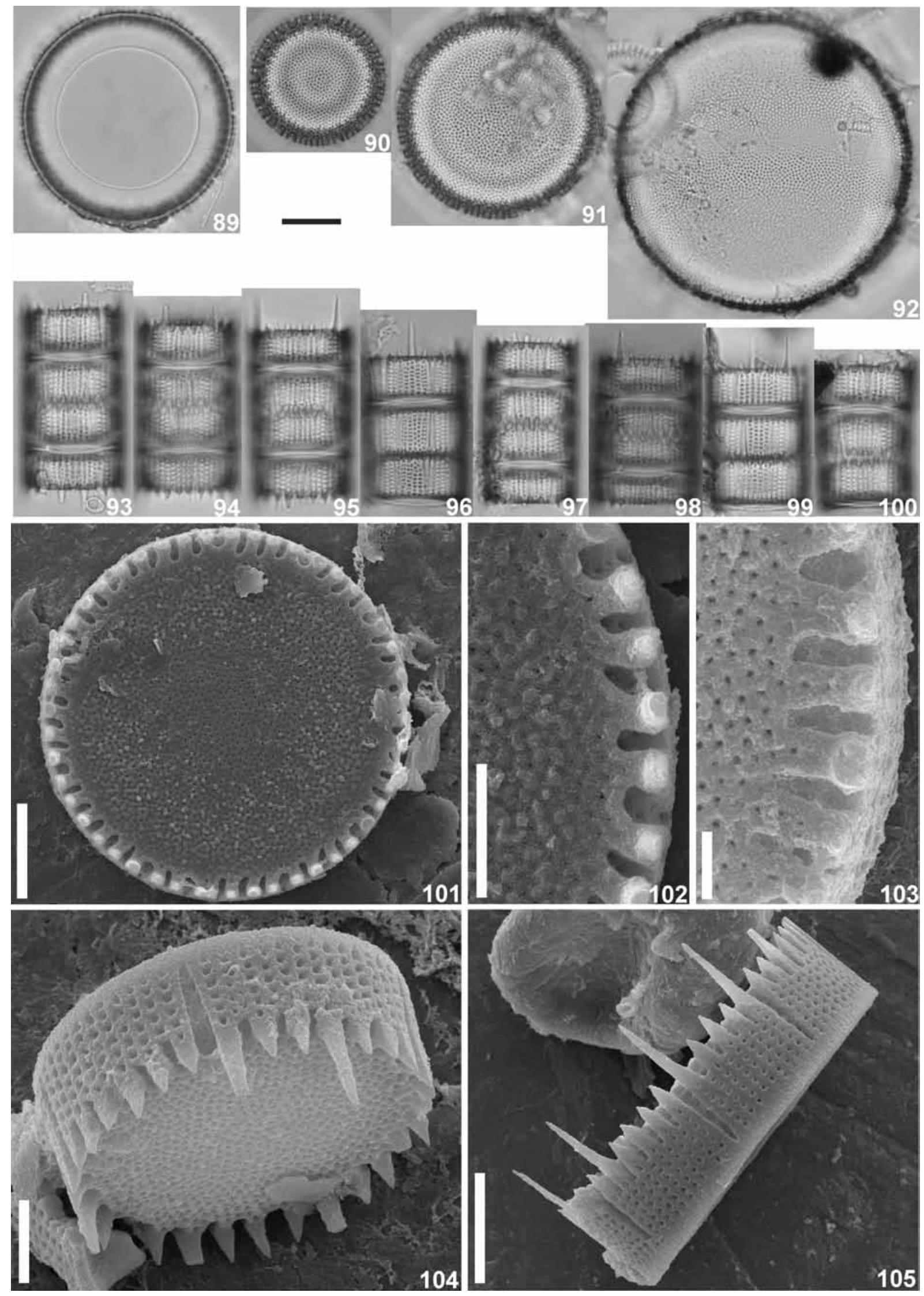

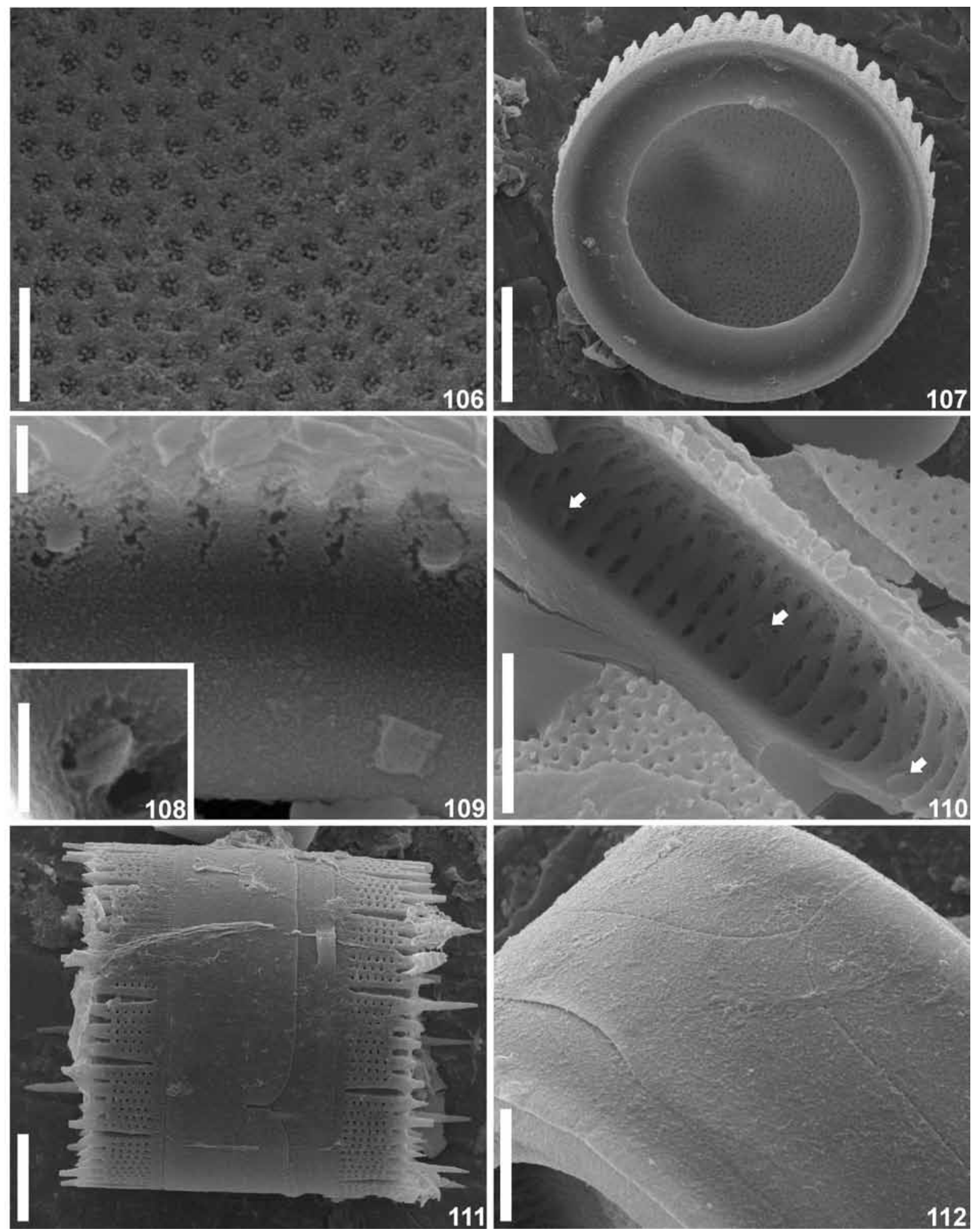

Figs 106-112. Melosira agassizii var. malayensis [Celesbe, Malay Arch, stub AS1325-01S (Figs 106, 107, 11, 112) and AS1325-02S (Figs 108-110)], SEM: (106) occlusion of areolae in internal view; (107) internal view of valve, ringleist highly developed; $(108,109)$ internal opening of rimoportula; (110) rimoportulae position on the inner side of the valve (arrows); (111-112) external aspect of the cingulum with open bands, evident ligule and antiligule. Scale bars $10 \mu \mathrm{m}(107,111), 5 \mu \mathrm{m}$ $(110,112), 2 \mu \mathrm{m}(106), 1 \mu \mathrm{m}(108,109)$. 